\title{
Background of travencore-cohin minor dispute survey: An analysis
}

J. Suresh

Article Chronicle : Received: 03.03.2018; Accepted : 30.11.2018

Key Words : Swaroopam, Desoms, Encroachments, Modus operandi, Arbitration, Khandoms

\begin{abstract}
The name of Travancore is an anglicized form of Sri-Vazhum-kodu, which developed to Thrivithankodu and later to Travancore which means 'the abode of prosperity' or a 'place where the Goddess of prosperity dwells'. Travancore was renowned in other parts of the world as Dharma Rajya. Erstwhile Cochin state, known in Malayalam Kochi, situated on the western coast of Kerala State. The state was originally known as Perumpadappu Swaroopam. With the emergence of the Cochin port, the rulers of Perumpadappu Swaroopam shifted their headquarters from Mahodayapuram to Cochin. The state is singularly diversified in its physical aspects as in its configuration. ${ }^{2}$ The significant features of Geography like rivers, lakes, climate, hills and forests, seacoast etc., are the vital factors in shaping the History of both the states. Erstwhile Travancore, 'the garden of India lies in the extreme south-west of Indian sub-continent. The dispute between Travancore-Cochin states was also related to encroachments and the right of establishing their power. The important disputes in this regards were related to Anthakaranazhi, Keezhcheri Desam, Thiruvamkulam Muri and Canal, Kaniannoor Desom etc. These disputes had existed only for a Decade. The minor disputes were emerged after the settlement of J.C.Hannyngton Commission, appointed by British as mediator. Both Travancore and Cochin had taken special interest in settling these minor disputes cordially without changing them into major issues. All these problems were settled with sustaining their rights and authorities.

HOW TO CITE THIS ARTICLE : Suresh, J. (2018). Background of travencore-cohin minor dispute survey:An anylisis. Asian J. Environ. Sci., 13(1\&2): 33-38, DOI: 10.15740/HAS/AJES/13.1and2/33-38.
\end{abstract}

Author for correspondence :

\section{J. Suresh}

Department of History,

University College,

Thiruvanathapuram,

(Kerala) India

Email : Sureshrosegarden

@ gmail.com 